\title{
Approaches to Interpreting Mesolithic Mobility and Settlement in Britain and Ireland
}

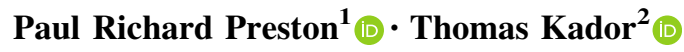

Published online: 12 June 2018

(C) The Author(s) 2018

\begin{abstract}
The Mesolithic communities of northwest Europe have generally been considered inherently mobile, and all the material evidence associated with them has been interpreted accordingly. This has resulted in entrenched, theoretically polemical and largely hypothetical mobility models, focusing on seasonal rounds and extraction activities. However, recent reanalyses of the ethnographic sources, and discoveries of both substantial and ephemeral Mesolithic structures, as well as new data from recent innovative lithic and scientific analyses (including DNA, isotope research on human remains, and geochemical analyses of lithic artefacts), have forced us to rethink the rather static models of Mesolithic mobility strategies. This paper, examining Mesolithic hunter-gatherer mobility and settlement models from Britain and Ireland, is part of that reassessment. In particular, it assesses the impact of the multiple lines of consilience on our understanding of Mesolithic habitation of landscapes. These include the archaeological evidence and the efficacy of recent theoretical and methodological approaches that have been employed to interpret it.
\end{abstract}

Keywords Mesolithic · Mobility - Settlement · Lithics · Ethnography · Models · aDNA · Isotope analysis

$\square$ Thomas Kador

t.kador@ucl.ac.uk

Paul Richard Preston

paul@lithoscapes.co.uk

1 Lithoscapes Archaeological Research Foundation, Rose House, Mellguards, Southwaite, Carlisle, UK

2 UCL Culture, University College London, WC1E 6BT London, UK 


\section{Introduction}

In writing on Mesolithic settlement and mobility (SM), we cannot ignore the contemporary geopolitical context, with vast migrations of people into Europe and concomitant discussions on social impacts, resources, territoriality and identity. It is no surprise that mobility and migration are back on the theoretical agenda. Contemporary events remind us of the role of such issues in our approaches to prehistory, while we review research developments on Mesolithic SM. It is therefore interesting to observe how the predominant interpretive paradigm has changed since the last substantive review of the British Mesolithic in a volume edited by Conneller and Warren (2006). For example, while Mesolithic habitation of the landscape was considered in the Conneller and Warren volume by McFadyen (2006), SM patterns were not addressed. Moreover, like the chapter on mobility in a near-contemporary volume (Wickham-Jones 2005), McFadyen's (2006) treatment of landscape was post-processual in outlook with a somewhat data-light discussion. Consequently, in both Wickham-Jones (2005) and McFadyen's (2006) reviews there was a notable absence of evaluation of the SM models (inter alia Binford 1980; Clark 1972) used at that time, which may stem from the fact that most SM models were largely processual in outlook (that is, adhered to a paradigm explicitly rejected by post-processualism). In contrast to the post-processual outlook of a decade ago, this paper evaluates the predominant emphasis of approaches based on scientific data, and how they relate to the SM models (still including Binford 1980; Clark 1972) deployed in British Mesolithic research today.

Despite their omission from Conneller and Warren (2006), both settlement patterns and mobility have remained recurring themes in Irish and British Mesolithic (IBM) research. Archaeologists have tended to use three main types of mobility models (see below), which have remained largely unquestioned (Preston 2013a, p. 29; Spikins 2000, p. 105). A balanced historiographic evaluation of SM models is urgently needed. Consequently, whilst the emphasis of this paper is on interrogating the developments and new data from the last decade, it is also necessary to evaluate the key SM models from the last 40 years, so we can investigate how recent studies have challenged or supported traditional interpretations. After outlining these mobility models, this paper will review the theoretical, methodological and ethnographic issues that they raise. In particular, the paper seeks to examine three main issues. First, it will consider the use of biological and lithic evidence within SM models. Second, it will seek to show that the scale on which archaeologists analyse this information-and in turn model mobility and settlement-has tended to be limited (i.e. either too narrow or too wide). Third, it will discuss the limited attempts to integrate hunter-gatherer social structure, and a detailed appreciation of how direct procurement or exchange would manifest themselves in the archaeological record, into SM models. The paper will conclude by highlighting that using a wider range of multi-scalar data in a way that is both replicable and ethnographically consistent is preferable to paradigmatically partisan approaches, unilinear models relying on one type of archaeological evidence, or weak methodologies. 


\section{Mobility Models}

Theoretically, the SM models deployed to explain Mesolithic hunter-gatherer movement in the landscape since the 1970s and 1980s have changed little. Therefore, this section briefly outlines the theoretical foundation for current work and critique: namely the Binfordian, Clarkian, and Territorial SM models.

\section{Binfordian Models}

These models derive from Binford's (1980) ethnographic and ethno-archaeological observations and classify hunter-gatherer settlement system variability into a continuum between foragers and collectors, who practised varying levels of residential or logistical mobility. Logistical mobility is the movement of small task groups to and from residential (base) camps to activity camps, while residential mobility describes the movements of the entire group from one base camp to another. Collectors achieve foraging efficiency when resources are patchy and seasonal by aggregating in a central place, making few residential moves, and undertaking frequent (often lengthy) logistical forays to obtain key resources (such as food, water and firewood). On the other hand, where resources are evenly distributed and available year-round, foragers, who have high residential mobility and invest little effort in logistical movements, achieve maximum foraging efficiency through moving people to food resources. Thus, the collector-forager continuum intimately links hunter-gatherer mobility to the environment. Though not the earliest of the proposed mobility models, the Binfordian models are perhaps the most influential and often form part of other models.

\section{Clarkian Transhumance Models}

Equally, some (e.g. Donahue and Lovis 2003, 2006a, b; Lovis et al. 2005; Lovis and Donahue 2015) still employ Clark's (1972) transhumance mobility model (Fig. 1a). This model and its recent reinterpretations are based on three elements: ethnographic observations of the Wik Monkan (Thomson 1949); a seasonality study on red deer remains (Fraser and King 1954); and an assumption of red deer aggregations and dispersals. Recent reinterpretations (Donahue and Lovis 2003, 2006a, b; Lovis et al. 2005; Lovis and Donahue 2015), like previous applications of this model (Jacobi 1978; Legge and Rowley-Conwy 1988; Mellars 1976; Pitts 1979), imply that Mesolithic hunter-gatherers undertook a predictable 'seasonal round' (sensu Binford 1980). This entails transhumance between smaller satellite inland/upland logistical camps geared towards the exploitation of specific seasonal resources and larger/long-term 'sheltered' lowland residential base camps on or near to the East Coast of England, like Star Carr, North Yorkshire. 

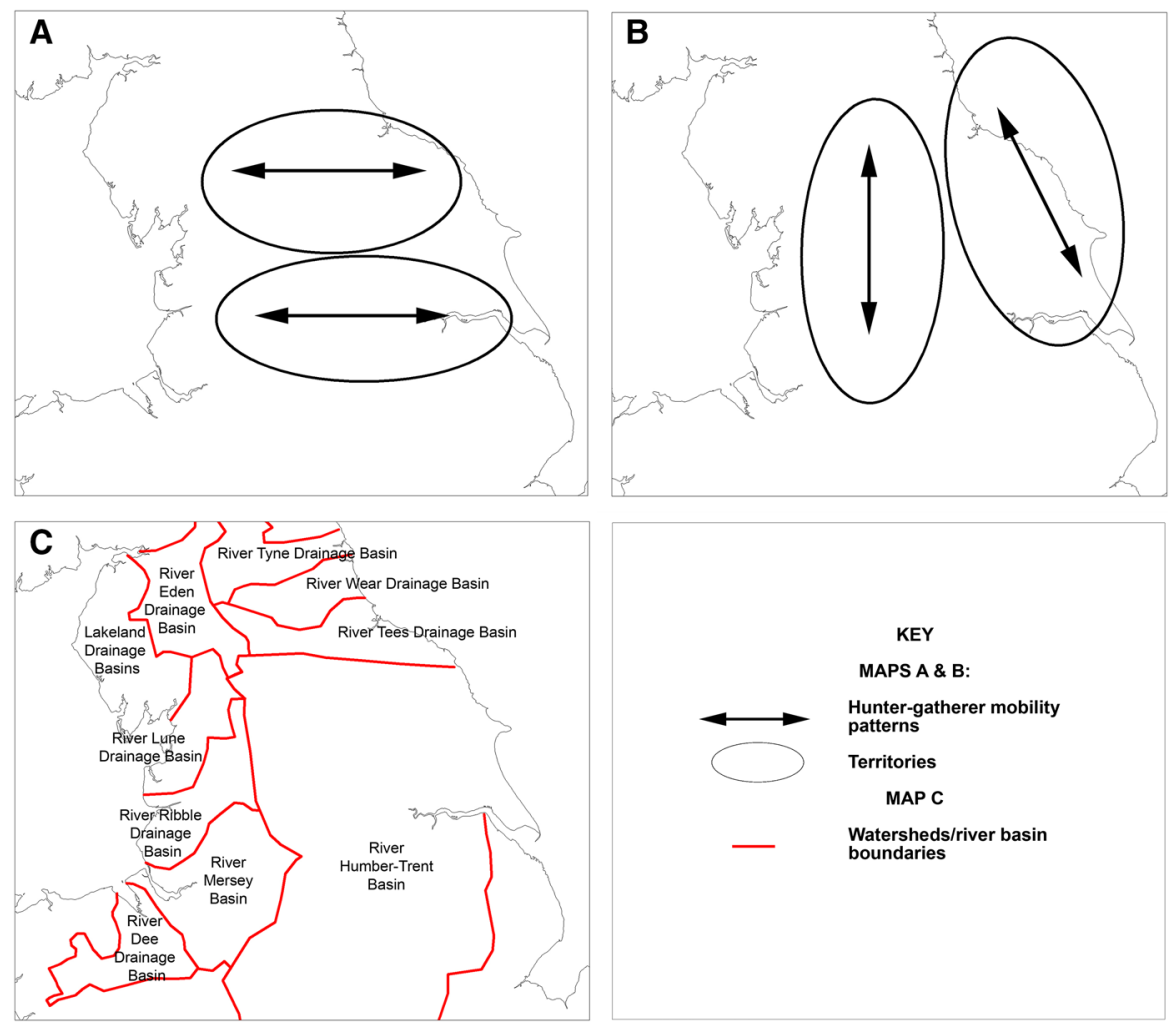

Fig. 1 Mesolithic mobility models. (based on Clark 1972; Evans et al. 2007, pp. 2161-2162; Preston 2011 [Fig. 10.3] p. 532; 2013a, b [Fig. 6] p. 30; Schulting and Richards 2000, pp. 58-59; Spikins 1996). The main groups of settlement and mobility models: Map A: The classic model of inland-coastal (eastwest) mobility in Clarkian models (e.g. Clark 1972). Map B: A typical Territory Model of independent coastal and inland populations with north-south mobility within these territories (i.e. Evans et al. 2007 interpretation of Schulting and Richards 2000). Map C: River Basin Territory Models where the main river basins in the north of England are individual social territories (e.g. as suggested by Spikins 1996)

\section{Territories Models}

The third and most recent group of SM models consider the nature and size of hunter-gatherer territories, based on a view that different contemporary groups had different social territories (Myers 2015; Waddington 2015). For example, stable isotope analysis of human and animal bones from the North of England (Clutton-Brock and Noe-Nygaard 1990; Richards et al. 2003; Schulting and Richards 2000, 2002a, 2009) have been interpreted to indicate the presence of both a coastal population that had a strong marine influence in their diets, and another, interior, population that predominantly had a terrestrial plant and animal diet (Fig. 1b). Thus, these separate populations have been taken to imply separate coastal and inland territories, something which directly contradicts the Clarkian model (Evans et al. 2007 pp. 2161-2162; 2010, p. 1158; Preston 2013a, p. 31). 
Similar observations have also been made for Ireland (Woodman 2004; Kador 2010).

This evidence has been taken (e.g. Myers 1986, 2015; Spikins 1996) to support the idea that river basins represent separate social territories (see Fig. 1c). For example, Spikins argued that each river basin was the territory of a band of about 350 people. She based her model on topographic features, such as rivers, that determine mobility; seasonality of resources; and 'dummy' population density estimates (Spikins 1996, pp. 92-93). Within these territories, several mobility strategies are perceived to have occurred simultaneously, but since only two resource locations are modelled, some sort of transhumance is implied (though not stated) between the coastal/winter/aggregation sites and upland summer dispersal sites within each territory (Preston 2013a, p. 31).

Now the main types of SM models deployed to interpret IBM have been examined, the paper will turn to a number of theoretical issues with them.

\section{Theoretical Issues}

Though not without their detractors (see below, Universal Laws, Binary Assumptions and the Seasonal Round), the three SM models remain a staple of the 'Mesolithic canon' (sensu Milner and Woodman 2005) and hence at the core of interpretations of the IBM, as they are perceived to be founded in scientific 'fact' and reliable ethnographic analogy. Yet on closer examination, the evidence becomes questionable, being underpinned by poor methodologies, non-replicable data, narrow ranges of artefact types, and simplistic ethnographic assumptions of the scale, social aspects, and nature of mobility. Some of these issues are considered below.

\section{Universal Laws, Binary Assumptions and the Seasonal Round}

The notion of a seasonal round comprises a balance between hunting in the uplands and fowling, fishing, and gathering at lowland camps, accompanied by periods of aggregation and dispersal between these locations. However, this binary division (hunting versus base camps) is problematic for the following reasons.

First, it led to archaeologists only seeking the 'opposite ends of the seasonal round' and ignoring variation (Preston 2011, p. 11; 2013a, p. 31; Spikins 2000, pp. 105-110) and the complex variety of site types seen in ethnography.

Second, based on archaeological evidence from Malham (the Yorkshire Dales, northern England), Donahue and Lovis (2003, p. 310) report that they could not identify any of the summer residential sites that Clark expected to be in the uplands. Instead, both they (Donohue and Lovis 2003) and Preston (2011) have demonstrated that there was regular use of upland habitats in the Early and Late Mesolithic, with logistical sites characterised by assemblages reflecting limited activities. This implies that the upland-lowland residential binary view is limiting.

Third, ethnographic accounts of seasonal rounds tend to be simplified interpretations that ignore differences between individuals and families over different timescales (Jochim 1991), and chronological conflations of evidence from different 
times into a single round (Conneller 2005, pp. 45-46). Assumptions of the predictability of resources (a key to the 'seasonal round' concept) cannot be substantiated through ethnographic literature (Spikins 1999, 2000). For instance, the Selk'nam of Tierra del Fuego varied their settlement patterns, with aggregation episodes sometimes determined by fortuitous events such as whale beachings (Bridges 1948, p. 313; Gusinde 1982a, b). Thus, we cannot assume that Mesolithic procurement strategies and settlement systems were seasonally predictable with a standard strategy for all environmental niches. Both ethnographic and archaeological evidence suggests that mobility strategies were dynamic, with multiple strategies operating simultaneously and with variation between individuals, families, bands and seasons (Jochim 1991, pp. 310-315; Spikins 2000, p. 111). We should therefore not expect simple correlations or universal laws of resources and mobility patterns (Kelly 1995, p. 120; Preston 2013a, pp. 31-32).

Fourth, Binford's forager-collector and logistical-residential continua are often misapplied as binary discrete types (Preston 2013a, p. 32): they are continua, as not all foragers are highly mobile, nor are all collectors nearly sedentary (e.g. see in Kelly 1983, 1992, 1995). The binary reduction of the model has led to the logistical and residential poles of the continuum being conflated with hunting and base camps, and so becoming synonymous with the upland and lowland sites respectively (Preston 2011, p. 16).

Finally, ethnographic analogies-often drawn from inappropriate environments-have continued to be employed in an oversimplified fashion (Jordan 2003). Hence, the behaviours described might not have even existed in the Mesolithic (Wickham-Jones 2005, p. 32).

\section{The Nature and Scale of Mobility and Settlement}

Most SM models, with the exception of that in Donahue and Lovis (2003, 2005), fail to account for the land exposed prior to the post-glacial inundation of Doggerland (Coles 2000; Gaffney et al. 2007, 2009; Hardy 2009) and Lower Fyldeland (i.e. the area between the present day northwest coast of England and the Isle of Man that is now covered by the Irish Sea between Morecombe Bay and Liverpool Bay) (Fitch and Gaffney 2011; Wessex Archaeology 2006). This omission has meant that the modelled territory sizes (e.g. as implied by Schulting and Richards 2000; Spikins 1996) are too small. Even though the Donahue and Lovis model (Donahue and Lovis 2003; Evans et al. 2007, 2010) incorporates current offshore land, the implied territories remain too small in scale. These small territories are at odds with lithic evidence (see below), and contrast with both European evidence and North American hunter-gatherer ethnographies suggesting they were more likely to have covered thousands of square kilometres (Donahue and Lovis 2006a, p. 248; Preston 2011, pp. 18-19; Wickham-Jones 2005, pp. 31-33). Thus, we have been grossly underestimating the size of territories and mobility within them.

It appears archaeologists have also been underestimating the amount of investment in dwelling architecture and site furniture. This includes evidence of houses from Star Carr (Conneller et al. 2010, 2012); Cass Ny Hawin I (Woodman 1987); Cass Ny Hawin II (Brown 2018); East Barns (Gooder 2007); South Queens 
Ferry/Echline Fields (Robertson et al. 2013); Mount Sandel (Woodman 1985); Lunt Meadows (Cowell 2018); Howick (Waddington 2007); various coastal shell middens (Mellars and Payne 1971); fish traps (McQuade and O’Donnell 2007); and shelters, built hearths, pits, and table stones at Central Pennine persistent places near transit routes (Preston 2011).

One of the main implications of the architectural evidence is that it challenges the assumptions of consistently high levels of mobility throughout the Mesolithic. These assumptions led many to discount the idea that there were permanent habitation sites that saw significant investment and frequent/regular re-visitation (Gaffney et al. 2009, p. 56). Clearly, Mesolithic people in Britain and Ireland displayed greater social, symbolic and physical investment in place than hitherto imagined. The architectural evidence suggests the possibility of more sedentary lifeways, much earlier than supposed, and with less mobile, semi-permanent residential places that were re-visited seasonally or for longer, over several generations. Given that most of the structures concerned date from relatively early parts of the Mesolithic this also has implications for the nature of the transitions to sedentism and Neolithic lifeways. The possibility of greater symbolic investment, as highlighted by these structures, also reminds us that we have generally neglected the social aspects of SM in our interpretations.

\section{Omission of Social Dimensions}

Some authors (e.g. Kelly 1992, 1995) have acknowledged the important social and political role of mobility among hunter-gatherers. The models in Fig. 1 focus on mobility as a practical and strategic concept, however, as Close (2000, p. 50) suggested, we should be interested in 'the act of moving'. In contrast to the Fig. 1 models, movement has seen explicit consideration within phenomenological landscape approaches (e.g. Tilley 1993, 1994; Tilley and Bennett 2004; Thomas 1996). Their goal is to investigate the experience and meaning of individual journeys. The link with the prehistoric past comes in the form of archaeological evidence, and as most of these accounts focus on the Neolithic period this is generally represented by tombs and other megalithic monuments (see contributions in Leary and Kador 2016). The problem in relation to pre-Neolithic times is that this highly visible architectural dimension is largely absent from the landscape.

To apply this approach to Mesolithic settings some researchers (e.g. Bradley 1998, 2000; Cummings 2000; Tilley 1994, 1995) theoretically 'monumentalised' visual features of the natural landscape (e.g. hilltops, rock outcrops, cliffs or shell middens). Mesolithic flint scatters are then seen to reference these 'natural monuments', rather than being meaningful in their own right. Hence 'Mesolithic sites are important for what they mark rather than what they make' (McFadyen 2006, p. 126); however, the connection between actual evidence for Mesolithic activity and the physical landscape features studied may be somewhat spurious. In addition, these conceptual explorations remain largely unsubstantiated with data (Jordan 2003; Preston 2011). A more effective means of consolidating the archaeological evidence with the landscapes that people traversed is required (see Kador 2013, p. 21). 
Perhaps one of the main reasons that the nature of mobility has been misunderstood is an overemphasis on one type of archaeological evidence-the biological (especially pollen and faunal evidence) —at the expense of anotherlithics. This paper will now turn to reviewing recent uses of lithic and biological evidence in interpreting SM.

\section{Biological Evidence}

Until very recently, IBM archaeologists tended to concentrate on only one or two artefact or ecofact types, and interestingly, despite the rarity of faunal evidence, many mobility models (e.g. Clark 1972; Legge and Rowley-Conwy 1988) are exclusively based on faunal evidence from only a few sites with favourable conditions of organic preservation (e.g. Star Carr, Thatcham or Mount Sandel, which are assumed to be lowland base camps).

Seasonality of sites, especially of Star Carr (and by implication the uplands elsewhere), has been discussed in detail by others (inter alia Caulfield 1980; Clark 1954, 1972; Dark 2003; Legge and Rowley-Conwy 1988; Lovis et al. 2005; Mellars and Dark 1998; Pitts 1979). It suffices to note that there is no agreement between the pollen or faunal evidence (e.g. red deer bones) being used to indicate different site types, seasons of occupation, direction of mobility, and site function. Also, the idea that mobility was restricted during winter months, as the uplands would have been inhospitable, cannot be substantiated. This is because no comparable seasonality studies have been undertaken for the upland sites where preservation conditions are less favourable. Thus, while the use of biological information to make seasonal and site function interpretations has tended to afford the impression (in the minds of many archaeologists) that the models rest on firm scientific foundations, the contradictions show this assumption is illusory.

However, the most significant recent developments in the study of SM in earlier prehistory again come from archaeological science, but studying human remains directly. The advance of stable and radiogenic isotope analysis, and ancient DNA (aDNA) sequencing, have started to open up new possibilities for Mesolithic mobility studies. Initial work in this field has focused primarily on 'dietary' isotopes $\left(\delta^{13} \mathrm{C}\right.$ and $\left.\delta^{15} \mathrm{~N}\right)$ in human remains, including Schulting and Richards' work on evidence from Ireland and Britain (Kador 2013; Kador et al. 2015; Richards et al. 2003; Schulting 2005; Schulting and Richards 2000, 2002a, b; Woodman 2004).

Some of the same remains, perhaps most notably those from Aveline's Hole (Schulting 2005) have also been analysed originally for strontium isotopes, providing a more direct reference to mobility. More recently, analysis of Mesolithic remains from Ireland for carbon, nitrogen and strontium isotopes (Kador et al. 2015) has highlighted the relative paucity of known Mesolithic human remains as one of the key challenges with isotope analysis in both Britain and, especially, Ireland. Given the small sample sizes and the lack of comparative data, it is very difficult to make conclusive pronouncements about human movement during the Mesolithic period based on these results. Yet, in other parts of Mesolithic Europe, such as the Danube Gorges (Boric and Price 2013), this approach has been employed relatively successfully, suggesting that a more systematic approach to isotope (especially 
strontium) analysis of the human remains from northwest Europe might also bring interesting results.

One further scientific methodology that has the potential of transforming our understanding of Mesolithic (population) movements is aDNA sequencing, successfully demonstrated for Scandinavia (Skoglund et al. 2014), the Low Countries (Lazaridis et al. 2014) and Central Europe (Bollongino et al. 2013). In contrast to isotope analysis, whole genome aDNA sequencing of a relatively small amount of human remains can provide extremely interesting insights. While the authors of this paper are aware of ongoing work in this field focusing especially on Ireland (Dan Bradley pers. comm.), to date only one application of this technology to British or Irish human remains has been published (Brace et al. 2018).

These new datasets and technological possibilities notwithstanding, the traditional dependence on biological material and the failure to integrate lithic evidence with it is surprising. While the next section foregrounds the discussion on lithic evidence, it does so with a view to integrating lithic datasets with other strands of evidence for Mesolithic SM.

\section{Lithic Evidence}

Lithics are the most ubiquitous artefacts on virtually all Mesolithic sites. Their raw materials originate from specific geological sources within certain geographical locations, corresponding to the initial stages in their chaînes opératoires (sensu Inizan et al. 1999, p. 14) and hence implying either individual/group movement or human interaction (e.g. exchange). Thus, theoretically, lithics are an attractive proxy for identifying movements and social territories. Despite this, lithics have often been neglected as the basis for SM Models for the British Mesolithic, in favour of, for example, biological evidence (e.g. Figure 1a, b), reflecting a poverty of understanding of the chaîne opératoire as a problem-solving behaviour. Lithic technology has nonetheless gradually come to play a more central role in interpretations of past hunter-gatherer lifeways (Myers 1989a, b; Torrence 1983, 1989; Zvelebil 1984). More recently still, the potential of lithic analysis for developing, testing and challenging SM models has been demonstrated (e.g. by Evans et al. 2007, 2010; Kador 2009b; Preston 2009, 2011, 2013a, b). In particular, raw materials have been employed successfully as a proxy for the identification of group movements and social territories.

One exception to the neglect of lithic data is Mellars' (1976) study attempting to refine Clark's model through the integration of typological lithic data (Preston 2011, p. 24; 2013a, b, p. 35). In order to place lithic assemblages on scales of size, permanence, and function, Mellars analysed the retouched component of Mesolithic lithic assemblages from both upland and lowland sites. Accordingly, he interpreted upland sites dominated by microliths as hunting camps, and the larger lowland sites dominated by scrapers and other lithics as implying a wider range of domestic activities and hence as base camps. This study had four significant shortcomings.

First, Mellars' lithic analysis oversimplifies the assemblage diversity through the omission of awls, non-formal tools, utilised tools, and debitage types (Myers 1987; Preston 2013a). Second, he assumed that form indicates function, while use wear 
(e.g. Evans 2009; Dumont 1985, 1988; Robson et al. 2018; Warren et al. 2009) and technological analyses (e.g. Finlay 2000, 2003; Myers 1986; Preston 2011) show that microliths have not been solely used as projectile points, and that scrapers were not just used for hide work. Third, Spikins (2000) argues that comparisons of tool ratios may give questionable indications of specific activities and tend to create artificial types by default. However, tool ratios are not meant to recreate huntergatherer site types. Instead, lithic ratios are an established heuristic for comparing assemblage composition and can be reliable, provided comparisons are technologically based and assumptions are clearly stated (Preston 2013a, p. 35). Instead, Preston (2013a, p. 35) states that Mellars' study was not limited by the use of ratios per se, but rather by the comparison of only a few types, a lack of explicit assumptions and methodology, and potentially erroneous functional interpretations. Fourth, rather than testing the Clarkian SM model with his data, Mellars simply used it to filter the results (Preston 2013a, b, p. 35). Despite these issues, the value of this study is that it represents the first attempt to integrate into a mobility model a wide-scale synthesis of lithic assemblages from across the landscape.

More recent attempts to use lithics to test SM models have proved more successful. Work in the Pennines (Evans et al. 2007, 2010; Donahue and Lovis 2003, 2006a, b; Lovis et al. 2005; Lovis and Donahue 2015) comparing the Clarkian (Fig. 1a) and Social Territories models (Fig. 1b) and the expected lithic distribution patterns associated with each is a good example of this. The latter model would rely on chert from the Northern Pennines (north of the Aire Gap, near Settle, North Yorkshire, England) and Southern Pennines (south of Longdendale, Derbyshire, England) being then distributed throughout the region, utilising the river valley systems, resulting in a spatially restricted distribution in these two upland zones. However, as geochemical analysis found no evidence of Northern Pennine cherts in the Southern Pennines and vice versa, east-west movement of material, as implied by the Clarkian model, was found to be the most likely mobility pattern.

While this is a powerful example of the potential of lithic evidence, it only represents part of the picture for two reasons. First, Evans and colleagues only analysed one raw material type (shiny black chert) of over twenty raw material types found on Mesolithic sites in the Pennines (Fig. 2). Second, the focus of their study omitted the Central Pennines (the uplands between the Aire Gap in the north and Longdendale in the south are sometimes confusingly also referred to as the South Pennines) between their two study areas, as well as the lowland areas to the west of the Pennines. Nonetheless, the value of these studies is that they have been able to verify some of the east-west transit along the river systems in a replicable and quantifiable way.

Preston (2011, 2013a, b) analysed the Mesolithic lithic material from over 700 sites in the Central Pennines, which the above study omitted. As this area has no known raw material sources, all lithic materials necessarily had to be imported (Fig. 2a) from an area covering the whole of the North of England, and potentially parts of Doggerland and Lower Fyldeland. A full description of the raw material sources and data outlined in Fig. 2 would take us beyond the scope of this paper and is too complex to assess here. However, it is sufficient to note that a range of geochemical analyses, including Laser Ablation Inductively Coupled Mass 

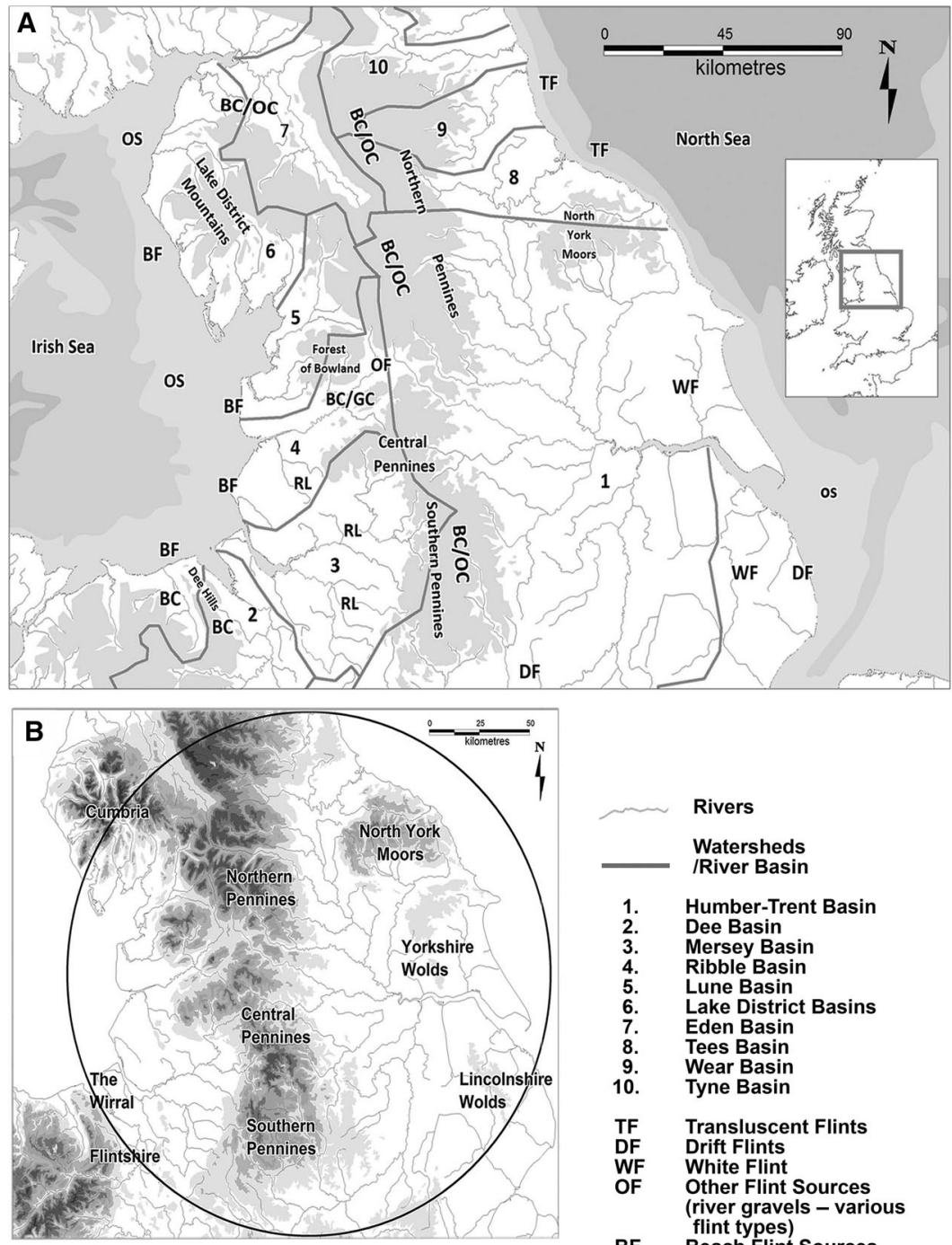

\section{Rivers}

Watersheds

/River Basin

1. Humber-Trent Basin

2. Dee Basin

3. Mersey Basin

4. Ribble Basin

5. Lune Basin

6. Lake District Basins

7. Eden Basin

8. Tees Basin

9. Wear Basin

10. Tyne Basin

TF Transluscent Flints

DF Drift Flints

WF White Flint

OF Other Flint Sources

Other Flint Sources
(river gravels - various

flint types)

BF Beach Flint Sources

BC (various types)

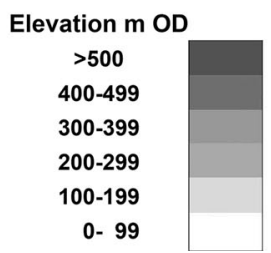

OC Other Cherts (various

types)

GC Grey Pinhole Chert

RL Rhyolite

os Offshore Flint

\& Chert Sources

Fig. 2 Raw material source locations in Northern England in relation to river basins. (after Preston 2011 [Fig. 7.17; Tabs. 7.21-7.26], 2013a, b [Fig. 7] p. 34). Map A: Raw material sources and river basins. Map $\mathrm{B}$ : The raw material hinterland for the Central Pennines 
Spectrometry (LA-ICP-MS), Inductively Coupled Plasma Mass Spectrometry (ICPMS), X-ray fluorescence (XRF), petrographic, and macroscopic analyses have contributed to a burgeoning robust database that supports these claims. These results are described and analysed by Bradley (2017), Brown et al. (2018), Clark and Dickson (2018), Dickson and Cherry (2018), Elliot (2018), Evans et al. (2007, 2010), Wolframm (2006), and Preston (2011, 2013a, 2018) for the Mesolithic; and Pettitt et al. (2015) and Rockman (2003) for Creswellian sites. While the latter study is on Creswellian archaeology, the raw material source data is integral to the debate for the Mesolithic as much of the same source geology was exploited in both periods. This raw material evidence has three main (yet potentially contradictory) implications for the SM models which concern the hypothesised cardinal direction of mobility, population sizes and the assumed existence of multiple territories including their potential effects on access to raw material resources (Fig. 1).

First, based on this data, and assuming direct procurement (discussed in more detail below), the location of the raw material sources in the hinterland (cf Fig. 2a, b) challenges the idea that mobility in the North of England was solely east-west or north-south, as implied by other SM models (e.g. Figure 1a). Indeed, if mobility was along the rivers, as has been suggested by Donahue, Lovis and colleagues (Donahue and Lovis 2006a, b; Lovis et al. 2008; Lovis and Donahue 2011, 2015), Spikins (1996), and Preston (2011), the large size of the Trent-Humber basin (Fig. 2a) might account for the predominantly west-east signal obtained by Evans et al. (2007, 2010; Donahue pers comm.).

The second implication (embedded in the Hinterland Territory Model in Fig. 3, which combines the raw material data with population density estimates) is that the multiple territories suggested in Fig. 1b may not have existed (Preston 2011, 2013a, b). For instance, Smith (1992, pp. 13-20) estimated Mesolithic population density at approximately 0.01 people per $\mathrm{km}^{2}$, using the number of people needed for sustainable breeding networks (200), minimum dietary requirements, and the ecological carrying capacity of the environment. Using this estimate, it is possible to show that since the Central Pennines covers an area of $2400 \mathrm{~km}^{2}$ it could only have a carrying capacity of 24 people and thus it could not have been a sustainable territory (Preston 2011, 2013a, b). Consequently, the Mesolithic people who visited this area must have come from a larger group. For Kelly (1995), such larger hunter-gatherer groups can include networks of up to (or even over) 300-500 people. The area required to sustain such a group can, in turn, be conjectured using Smith's density estimates. Thus Fig. 3 shows how the minimum sustainable Early and Late Mesolithic territories can be estimated. Preston (2011, 2013a, b) noted that a) the areas in Fig. 3 are striking similar to the raw material hinterland (Fig. 2b); b) there was not sufficient space for two adjacent contemporary social territories in Northern England during the Early Mesolithic, and thus a plausible reconstruction would be a territory that covers most of Northern England and possibly extends into Doggerland and Lower Fyldeland (the black circles in Fig. 3a). Similarly, due to rising sea levels, there was even less land available for occupation during the later Mesolithic, and Fig. 3b shows that adjacent territories would be not have been sustainable without extremely high levels of intermarriage, such that the separate 


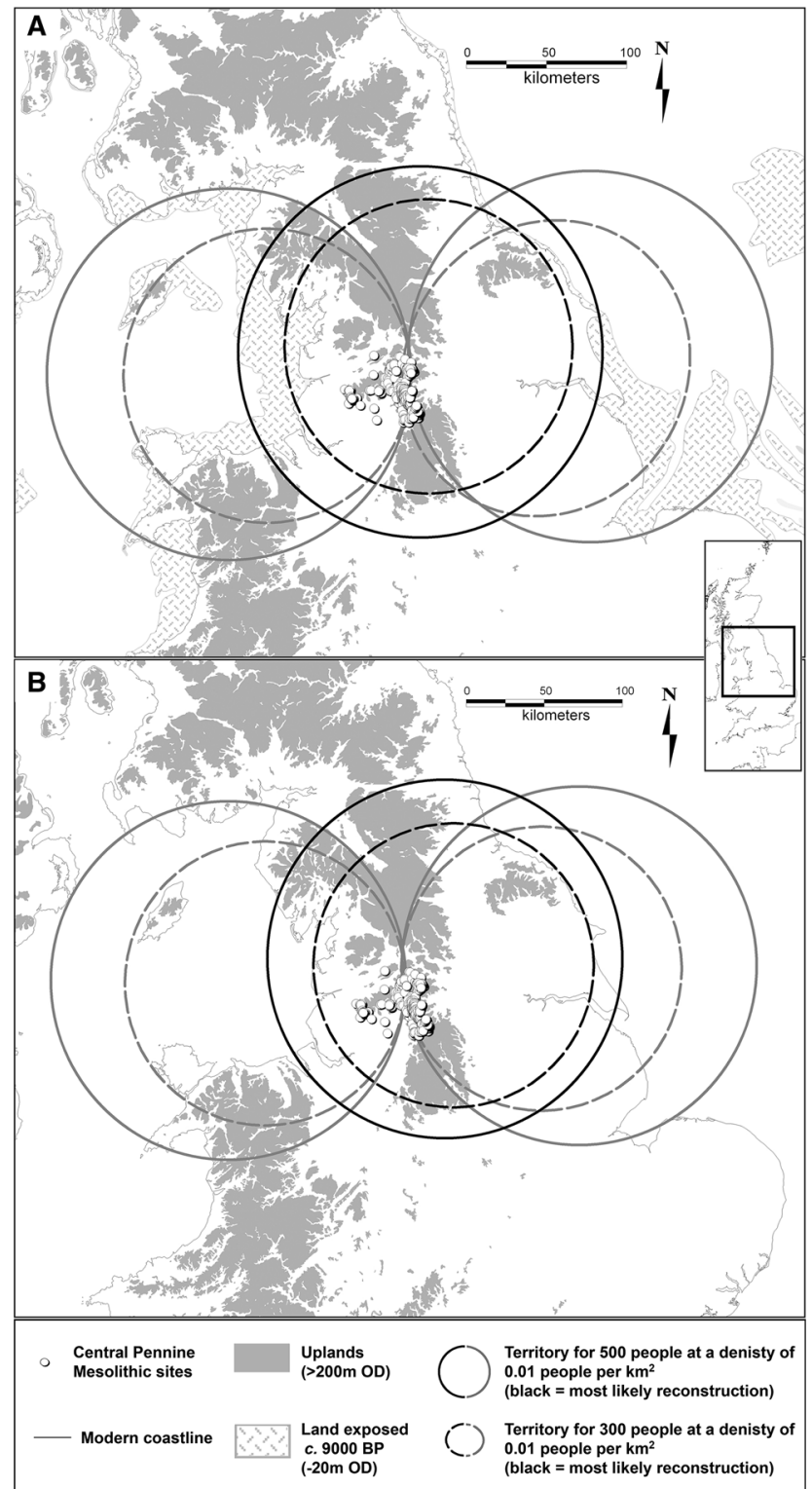

Fig. 3 Hinterland-Territory Model social territory reconstructions for groups of 300 and 500 people. (After Preston 2011 [Figs. 7.19 \& 7.20] pp. 399-400, 2013a, b, [Fig. 8] p. 40). These models show territory reconstructions for groups of 300 (the smaller dashed circles) to 500 people (the larger circles) at a density of 0.01 people per $\mathrm{km}^{2}$, as estimated by Smith (1992) for the Early Mesolithic (Map A) and the Late and Terminal Mesolithic (Map B). These reconstructions imply that only the central circles in A and B had the space for a viable breeding population (i.e. minimum people $n=200$ ). This rules out the possibility of two adjacent territories, meaning that there was only one large territory in the North of England during the Mesolithic (with possible extensions in the former on to Doggerland and Lower Fyldeland [i.e. the area now covered by the Irish Sea between the Isle of Man and Morecambe Bay and Liverpool Bay on the present-day northwest coast of England]) 
groups would not have been independent of each other and so would have ceased to exist as separate entities in a very short space of time. Consequently, the most likely reconstruction would be the black circles in Fig. $3 \mathrm{~b}$. This model implies that there is likely to have been only one population inhabiting northern England throughout the Mesolithic (Preston 2011, pp. 392-404, 2013a, pp. 38-40); this, however, is a reductive simplification and there is an alternative model that combines the first two implications.

The third implication of the raw material data is the changing frequencies of different rock types in the archaeological record. For example, Preston (2011, 2013a, b, 2018) argues that it follows from the first two implications that transhumance within a single river basin model, as the models in Fig. 1 imply, is not likely. Instead, mobility would probably have been more consistent with patterns seen in North American Boreal hunter-gatherer analogues (see Fig. 4 for examples) that is, cyclically shifting over seasonal, annual or generational scales between different river basins. Thus, if the north of England was a single territory (Fig. 3) and mobility was in multiple directions (Fig. 2), then movement would range across different river systems at different times. This would result in differential access to raw material sources at different times depending on which river basins were inhabited and the geology within them (Fig. 2a). The Nexus model (Fig. 4) could therefore explain the distinct change in frequency of both the quantity and types of raw materials found on Central Pennine Early, Late and Terminal Mesolithic sites in relation to long distance logistical mobility (Preston 2011, 2013a, b, 2018). Therefore, the three implications of the raw material data provide a useful challenge to the traditional Clarkian (Fig. 1a) and territory models (Fig. 1b and c).

However, both the Hinterland Territory Model (Fig. 3) and the Nexus Model (Fig. 4) are reductive, and are not intended to be a facsimile of actual events. They are necessarily simplified to allow different variables to be tested, and thus have some weaknesses. For example, neither model integrates the impact of the changing Mesolithic environment which would have profound implications for mobility and the distribution of resources. Also, the population density estimates in the Hinterland Territory Model are relatively crude. It is, therefore, possible that the congruence of the raw material hinterland and the population density is chance rather than a specific pattern. Furthermore, if the Hinterland Territory Model (Fig. 3) is interpreted as an ethnolinguistic territory, then the exact relationship between band, clan, and ethnographic group ranges is undetermined within this space. Similarly, while, the Nexus Model could accommodate the notion of band or clan movements for the hypothesised mobility cycles, the exact nature of the social structures needs more attention. For instance, if the raw material source distribution (i.e. hinterland: Fig. 2b) in the Nexus Model (Fig. 4) is viewed as an ethnolinguistic territory, it is conceivable that this view would accommodate Spikins' (1996) idea that each river basin is a band or small clan range. However, this would negate the possibility of direct procurement and thus the Nexus Model. On the other hand, if the raw material hinterland is assumed to be a band or clan level territory, then the Nexus Model is valid, which means the population density would necessarily be smaller and the ethnolinguistic group area much bigger. Therefore, in this crucial point the Hinterland Territory and the Nexus Model are potentially at odds. At 


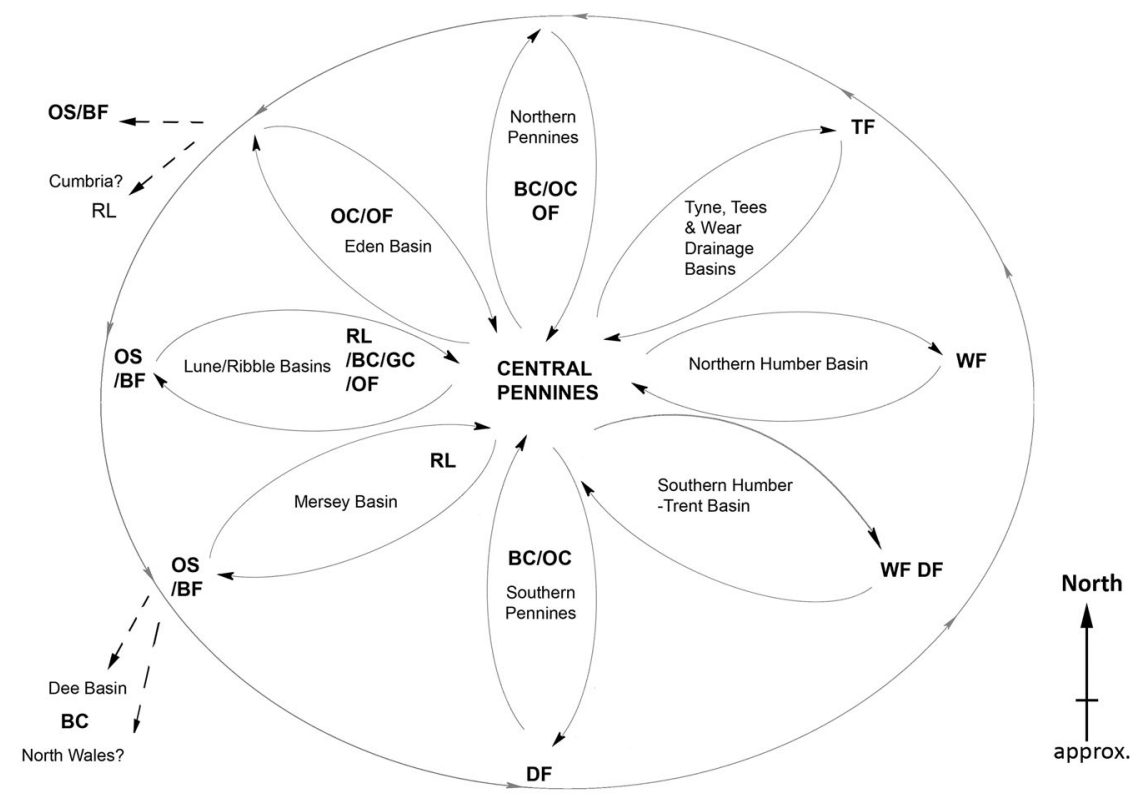

\section{TF Translucent flint sources \\ DF Drift flint sources \\ WF White flint sources \\ OF Other secondary flint sources (river gravels) \\ BF North West coast beach flint \\ BC Black chert \\ OC Other chert types \\ GC Grey pinhole chert \\ RL Rhyolite sources \\ OS Offshore flint and chert sources}

\author{
Changes in the \\ mobility cycle \\ each season, year, or \\ generation
}

\section{Seasonal/ logistical mobility cycles}

Fig. 4 The Pennine Nexus Hypothesis. (after Preston 2011 [Fig. 7.22] p. 407, 2013a, b [Fig. 9] p. 42). This model hypothesises the relationship between the raw material sources, the river drainage systems, and hunter-gatherer mobility relative to their geographical situations. The model combines four main components: (1) it assumes direct procurement; (2) mobility is in multiple directions, within a single northern territory as implied by the Hinterland Territory model; (3) it envisages group mobility as cyclically shifting between different systems over various temporal scales (e.g. seasonal, annual or generational) - a mobility pattern consistent with ethnographically appropriate Boreal hunter-gather analogues as suggested and described by Donahue, Lovis and colleagues (Donahue and Lovis 2006a, b; Lovis and Donahue 2011; Lovis et al. 2005, 2008), such as the Kutchin, Dunne-Za Beaver, Sahtu Hare, Chipewyan, Anishinaabe, Ojibwa, and the Naskapi and Montagnais Cree; iv) lithic raw material variation data from over 700 Central Pennine Mesolithic sites (Preston 2011, 2018). The hypothesised mobility transit routes illustrated should not be taken literally. Instead, the conceit of the model is to explain the distinct variation of raw materials assemblages (described in Preston 2011, 2018) through time that is evident on Central Pennine Early Mesolithic Star Carr and Deep Carr type, Late Mesolithic micro-scalene triangle-microlith-dominated, and Terminal Mesolithic rod-dominated sites

present the exact interpretation is equivocal, but the value of these models is that they highlight the fact that Mesolithic mobility was dynamic, on a larger scale than we have hitherto appreciated, and that our SM models lack coherent, 
ethnographically consistent social structures, thus demonstrating that we have been viewing British Mesolithic mobility as too static and on too small a scale (Preston 2011, 2013a).

One key weakness of both the Hinterland Territory and Nexus models is that they exclusively assume direct procurement of raw materials. For Preston (2011, 2013a, b, 2018), this seemed reasonable for three main reasons. First, while the archaeological literature often portrays direct procurement and exchange as binary opposites, ethnographic evidence (e.g. see in Kelly 1995) generally suggests that this is rarely the case in hunter-gatherer societies, where the two approaches are combined depending on a number of environmental, social and other factors. Indeed, as noted for both the Hinterland Territory and Nexus models, social identity/ structure and territory size may have determined which would be more likely to have been used. This is too variable to model, thus necessitating a choice of one or the other. Secondly, since archaeologists have yet to fully describe how direct procurement or exchange manifests itself in the archaeological record, either is ontologically appropriate. Thirdly, traditionally, archaeologists have tended to describe lithic resource procurement in the Early Mesolithic as direct procurement and in the Late Mesolithic as exchange, based on assumed population densities and territory sizes. In other words, currently our interpretive frameworks do not allow us to identify or determine which option is the most valid. Therefore, at this juncture, since part of the modelling process is a simplification of variables and the most appropriate ontological choice of direct procurement or exchange is equivocal, as long as the assumption is explicitly stated, either is valid. The value of modelling is that by changing the variables we can postulate the effects of each.

Given this broader difficulty in understanding the effects of exchange on a lithic assemblage and how they are manifested in the archaeological record, a number of studies have postulated exchange as the likely variable. In particular, there have been studies focusing on the sources of raw materials for artefact manufacture (Kador 2009a, b; Little 2009a; Woodman and Johnston 1991), and the existence of exchange networks involving the movement of both lithic raw materials and artefacts has been postulated in the (recent) literature for several parts of the IBM.

Working in both northeast and eastern Ireland, Kador (2007, 2009a) suggested a web of social networks connecting several regions of Ireland and potentially involving a combination of exchange and other procurement strategies. Moreover, he identified particular locations that appear to have served as nodes or centres where people from different parts of the island came together, to exchange not just raw materials but possibly intangible things such as news or gossip, as well as to forge or renew social ties. Based on the distribution of specific types of later Mesolithic lithic artefacts, Kador proposed that many of these locations at the centre of people's movements and interactions may have focused on particular points along the courses of some of Ireland's main river systems (Kador 2007, pp. 39-40; 2009a, p. 77), highlighting the centrality of waterbodies to people's movements during the Mesolithic period (cf. Fig. 1c above for England and see also below).

The evidence from Irish later Mesolithic material is replicated by similar finds from across many parts of Mesolithic Britain. Perhaps the most famous example for long distance movement of material there comes in the form of the transportation of 
Portland chert (Cunliffe 2001, p. 129), but other materials are also known to have moved over considerable distances (e.g. Care 1982, pp. 278-279; Hind 2004, p. 155). There is also evidence for the movement of raw materials in Mesolithic western Scotland, for instance, Rhum bloodstone and Arran pitchstone, which evidently entailed offshore travel by boat (Saville 1994, pp. 57-58; Clarke and Griffiths 1990, p. 156; Warren 2000, p. 98; 2005, p. 140; Ballin 2015, pp. 5-16), and for the use of non-local raw materials, up to100 $\mathrm{km}$ from their source, in South Wales (Barton et al. 1995, p. 110).

On a broader scale still, the question of contacts between Britain and Ireland during the Mesolithic periodically recurs in the literature (see Bradley, 2007, p. 35; Cooney 2000, p. 13; Kador 2013; Thomas 2004; Woodman 2000; Woodman et al. 2006). With the exception of some isolated finds of Antrim flint on the Mull of Kintyre (Saville 1999, 2003, pp. 346-347), and clear indications of links with the Isle of Man from both Britain and Ireland (McCartan 2003, pp. 337-338), the evidence available to date for such contacts prior to the fourth millennium BC is very limited.

Nonetheless, there is sufficient data, such as that from the Isle of Man and the Scottish examples cited above, to suggest that water travel both offshore and inshore was an important means of communication during the Mesolithic period of these islands. As in Kador's findings mentioned above, Little (2009b, pp. 703-704) has proposed that the concentration of diagnostic Mesolithic lithic artefacts at river/lake junctures in the Irish Midlands represents people 'returning to familiar places within the landscape [and] suggests that remembrance and knowledge sharing was part of the social fabric' of their lives, as much as the exploitation of migratory fish passing these locations. Thus, both Little (2009b) and Kador (2009b), working in the centre and east of Ireland respectively, discuss the relationship between lithic artefacts and the landscape as a fluid and interwoven one, giving expression to Warren's (2006, p. 17) suggestion of 'exploding artefacts back out to their relationships across the landscape'. Driscoll (2009a), employing a similar approach, highlighted the largely untapped potential of exploring Mesolithic activity in the west of Ireland.

While most IBM research on lithics has focused on flint and chert, Kador (2009b), Driscoll (2009b), Driscoll et al. (2014) in Ireland, and Preston (2011) and Dickson (Clark and Dickson 2018; Dickson and Cherry 2018) in Britain have also examined the exploitation and distribution of non-flint/chert materials like tuff, rhyolite, quartzite and silicified dolomite. They argue that our narratives of IBM are heavily biased towards flint and chert artefacts and that recognising other 'tool stones' and studying their sourcing, use and distribution could have profound effects on our understanding of Mesolithic material culture and lifeways more generally.

\section{Conclusion}

Our challenge for this paper was to summarise the changes and developments in Mesolithic mobility studies in Ireland and Britain over the last decade. However, we found that discussing recent approaches necessitated engaging with the traditional models of hunter-gatherer mobility that have dominated Mesolithic archaeology for 
nearly half a century, as these models still dictate contemporary discourse on mobility in the Mesolithic. Therefore, at the heart of our contribution stands the question of the purpose of such models. Are they to recreate 'hunter-gatherer types', or are they constructed as heuristic devices that allow archaeologists to test our assumptions about past human movement and mobility? The discussion here has demonstrated the previously expressed view (e.g. Spikins 2000a) that the inconsistencies of these models, for example with ethnographic data, but also with much archaeological evidence, mean that they are unsuitable for identifying 'hunter-gatherer' types.

The models' efficacy for testing assumptions can also be debated. However, their application to archaeological datasets from Britain and (to a lesser extent) Ireland has led to continuous evaluation and modification of new models, based on them. These have revealed inadequacies in how archaeologists interpret the archaeological evidence, resulting in renewed cycles of testing and reassessment. The authors of this paper would argue that this is precisely the function of a model. By extension, this means that it will never be possible to construct a model for Mesolithic mobility and settlement patterns that is completely satisfactory in explaining all the evidence, as in fact being unsatisfactory, and thus making archaeologists re-evaluate the evidence, is the most (perhaps the only) useful contribution of such models.

Apart from reworking of the old models and proposing new ones, especially for the north of England, our review has also focused on the role of new types of evidence, such as the ever-growing number of sites that have produced substantial, semi-permanent structures, and the opportunities for Mesolithic mobility studies brought by bioarchaeological applications such as isotope analysis and aDNA sequencing. Additionally, we have remarked on the curious fact that many of the mobility models have failed to engage with the nature of the most abundant type of evidence for Mesolithic Britain and Ireland, lithic artefacts, as well as noting the binary approach usually applied to direct procurement and the exchange of materials. Consequently, we have attempted to draw attention to recent studies that have sought to overcome these disconnects.

To close, we wish to consider the legacy of recent research on Mesolithic mobility and wonder where mobility and settlement studies might go over the next decade. It is evident that ethnoarchaeological and actualistic studies need to be undertaken to evaluate the effects of direct procurement, exchange and other cultural processes on site taphonomy. Furthermore, ethnographically informed consideration of social composition and identities need to be included in our models. Additionally, more research is needed on lithic raw material sourcing, and this data needs to be better integrated with the now-mature studies on stable isotopes and other biological material.

Acknowledgements The authors would like to thank Graeme Warren, and Chantal Conneller for inviting both of them to speak at the Mesolithic session at the Theoretical Archaeology Group Conference 2014, and to write this paper. They are also grateful to Ben Elliott and Aimée Little for their editorial advice, comments and support. They thank the reviewers for their enlightened comments and suggestions and Adrian Evans, Randy Donahue and Bill Lovis for permission to reproduce and modify elements of Fig. 1. Paul R. Preston also acknowledges the funding from Lithoscapes Archaeological Research Foundation for current research, and previous Doctoral funding (upon which the Nexus model and Hinterland-Territory 
Model described in this paper is based) from Oxford University, Hertford College, the Council for British Archaeology (Challenge Fund) and Rochdale Ancient Parish Education Fund.

Open Access This article is distributed under the terms of the Creative Commons Attribution 4.0 International License (http://creativecommons.org/licenses/by/4.0/), which permits unrestricted use, distribution, and reproduction in any medium, provided you give appropriate credit to the original author(s) and the source, provide a link to the Creative Commons license, and indicate if changes were made.

\section{References}

Ballin, T. B. (2015). Arran pitchstone (Scottish volcanic glass): New dating evidence. Journal of Lithic Studies, 2(1), 5-16. https://doi.org/10.2218/jls.v2i1.1166.

Barton, R. N. E., Berridige, P. J., Walker, M. J. C., \& Bevins, R. E. (1995). Persistent places in the Mesolithic landscape: An example from the Black Mountain uplands of South Wales. Proceedings of the Prehistoric Society, 61, 81-116.

Binford, L. R. (1980). Willow smoke and dogs' tails: Hunter-gatherer settlement systems and archaeological site formation. American Antiquity, 45, 4-20.

Bollongino, R., Nehlich, O., Richards, M. P., Orschiedt, J., Thomas, M. G., Sell, C., et al. (2013). 2000 years of parallel societies in Stone Age Central Europe. Science, 342, 479-481.

Boric, D., \& Price, T. D. (2013). Strontium isotopes document greater human mobility at the start of the Balkan Neolithic. Proceedings of the National Academy of Sciences of the USA, 110, 3298-3303. https://doi.org/10.1073/pnas.1211474110.

Brace, S., Diekmann, Y., Booth, T. J., Faltyskova, Z., Rohland, N., Mallick, S., et al. (2018). Population replacement in early Neolithic Britain. https://doi.org/10.1101/267443.

Bradley, R. (1998). The significance of monuments: On the shaping of human experience in Neolithic and Bronze Age Europe. London: Routledge.

Bradley, R. (2000). An archaeology of natural places. London: Routledge.

Bradley, R. (2007). The prehistory of Britain and Ireland. Cambridge: Cambridge University Press.

Bradley, S. (2017). Archaeological and geochemical investigation of flint in Britain and Ireland. PhD thesis. Preston: University of Central Lancashire.

Bridges, L. E. (1948). Uttermost parts of the earth. London: Hodder \& Stoughton.

Brown, F. (2018). Cass ny Hawin II \& III: A new Mesolithic house and pit structures on the Isle of Man. In A. Myers \& P. R. Preston (Eds.), The Mesolithic of north-western England. Archaeology Northwest (Vol. 4, pp. 100-122). Salford: Council for British Archaeology Northwest/Lithoscapes Archaeological Research Foundation/Department of Applied Archaeology, University of Salford.

Brown, F., Dickson, A. J., Gregory, R., \& Zant, J. (2018). The archaeology of the Carlisle northern development route. Oxford Archaeology Monograph. Lancaster: Oxford Archaeology North.

Care, V. (1982). The collection and distribution of lithic materials during the Mesolithic and Neolithic periods in southern England. Oxford Journal of Archaeology, 1, 269-285. https://doi.org/10.1111/j. 1468-0092.1982.tb00314.x.

Caulfield, S. (1980). Star Carr: An alternative view. Irish Archaeological Research Forum, 5, 15-22.

Clark, J. G. D. (1954). Excavations at Star Carr: An early Mesolithic site at Seamer near Scarborough, Yorkshire. Cambridge: Cambridge University Press.

Clark, J. G. D. (1972). Star Carr: A case study in bioarchaeology (Vol. 10). New York: Addison-Wesley.

Clark, P., \& Dickson, A. (2018). A note on the implementation of an industrial-scale excavation methodology to recover a large Mesolithic lithic assemblage at Stainton West, Carlisle. In A. Myers \& P. R. Preston (Eds.), The Mesolithic of North-Western England. Archaeology Northwest (Vol. 4, pp. 198-209). Salford: Council for British Archaeology Northwest/Lithoscapes Archaeological Research Foundation/Department of Applied Archaeology, University of Salford.

Clarke, A., \& Griffiths, D. (1990). The use of bloodstone as raw material for flaked stone tools in the west of Scotland. In C. R. Wickham-Jones (Ed.), Rhum, Mesolithic and later sites at Kinloch: Excavations 1984-86. Society of Antiquaries of Scotland Monograph 7 (pp. 149-156). Edinburgh: Society of Antiquaries of Scotland. 
Close, A. E. (2000). Reconstructing movement in prehistory. Journal of Archaeological Method and Theory, 7, 49-77.

Clutton-Brock, J., \& Noe-Nygaard, N. (1990). New osteological and C-isotope evidence on Mesolithic dogs: Companions to hunters and fishers at Star Carr, Seamer Carr and Kongemose. Journal of Archaeological Science, 17, 643-653.

Coles, B. J. (2000). Doggerland: The cultural dynamics of a shifting coastline. Geological Society, London, Special Publication, 175(1), 393-401. https://doi.org/10.1144/gsl.sp.2000.175.01.27.

Conneller, C. (2005). Moving beyond sites: Mesolithic technology in the landscape. In N. Milner \& P. Woodman (Eds.), Mesolithic studies at the beginning of the 21st Century (pp. 42-55). Oxford: Oxbow.

Conneller, C., Milner, N., \& Taylor, B. (2010). Mobility and dwelling: Changing modes of landscape engagement over the Pleistocene/Holocene transition: A case study from the Vale of Pickering. In P. Arias \& M. Cueto (Eds.), Meso2010: The eighth international conference on the Mesolithic in Europe, Santander 13th-17th 2010: Final programme and abstracts (p. 56). Santander: Instituto Internacional de Investigaciones Prehistoricas de Cantabria.

Conneller, C., Milner, N., Taylor, B., \& Taylor, M. (2012). Substantial settlement in the European Early Mesolithic: New research at Star Carr. Antiquity, 86(334), 1004-1020.

Conneller, C., \& Warren, G. (Eds.). (2006). Mesolithic Britain and Ireland: New approaches. Stroud: Tempus.

Cooney, G. (2000). Recognising regionality in the Irish Neolithic. In A. Desmond, G. Johnson, M. McCarthy, J. Sheehan, \& E. Shee Twohig (Eds.), New agendas in Irish prehistory (pp. 47-65). Dublin: Wordwell.

Cowell, R. (2018). An interim characterisation of two potential Later Mesolithic structures at Lunt Meadows Site 1, Sefton, Merseyside, England. In A. Myers \& P. R. Preston (Eds.), The Mesolithic of North-Western England. Archaeology Northwest (Vol. 4, pp. 71-99). Salford: Council for British Archaeology Northwest/Lithoscapes Archaeological Research Foundation/Department of Applied Archaeology, University of Salford.

Cummings, V. (2000). Myth, memory and metaphor: The significance of space, place and landscape in Pembrokeshire. In R. Young (Ed.), Mesolithic lifeways: Current research from Britain and Ireland. Leicester Archaeology Monographs 7 (pp. 87-96). Leicester: University of Leicester.

Cunliffe, B. (2001). Facing the ocean: The Atlantic and its peoples 8000 BC-AD 1500. Oxford: Oxford University Press.

Dark, P. (2003). Dogs, a crane (not duck) and diet at Star Carr: A response to Schulting and Richards. Journal of Archaeological Science, 30(10), 1353-1356.

Dickson, A., \& Cherry, P. (2018). Recent research in the Mesolithic of Cumbria. In A. Myers \& P. R. Preston (Eds.), The Mesolithic of North-Western England. Archaeology Northwest, New Series 4 (pp. 140-197). Salford: Council for British Archaeology Northwest/Lithoscapes Archaeological Research Foundation/Department of Applied Archaeology, University of Salford.

Donahue, R. E., \& Lovis, W. A. (2003). Initial evaluation of Grahame Clark's model of Mesolithic transhumance in Northern England: A perspective from the Pennine uplands. In L. Larsson, H. Kindgren, K. Knutsson, D. Loeffler, \& A. Akerlund (Eds.), Mesolithic on the move: Papers presented at the Sixth International Conference on the Mesolithic in Europe, Stockholm 2000 (pp. 310-315). Oxford: Oxbow.

Donahue, R. E., \& Lovis, W. A. (2006a). Regional settlement systems in Mesolithic Northern England: Scalar issues in mobility and territoriality. Journal of Anthropological Archaeology, 25, 248-258.

Donahue, R. E., \& Lovis, W. A. (2006b). Regional sampling and site evaluation strategies for predicting Mesolithic settlement in the Yorkshire Dales, England. In E. Rensink \& H. Peeters (Eds.), Preserving the early past: Investigation, Selection and preservation of Palaeolithic and Mesolithic sites and landscapes (Vol. 31, pp. 13-24). Amersfoort: Rijksdienst voor het Outheidkundig Bodemonderzoek (Nederlandse Archeologische Rapporten).

Driscoll, K. (2009a). The early prehistory in the west of Ireland: Investigations into the social archaeology of the Mesolithic, west of the Shannon, Ireland. In S. McCarton, R. Schulting, G. M. Warren, \& P. C. Woodman (Eds.), Mesolithic horizons: Papers presented at the seventh international conference on the Mesolithic in Europe, Belfast 2005 (pp. 880-881). Oxford: Oxbow.

Driscoll, K. (2009b) Exploring the chaîne opératoires in Irish quartz lithic traditions: Current research. Internet Archaeology, 26. http://intarch.ac.uk/journal/issue26/driscollb_index.html. Accessed 3 Oct 09 
Driscoll, K., Menuge, J., \& O'Keeffe, E. (2014). New materials, traditional practices: A Mesolithic silicified dolomite toolkit from Lough Allen, Ireland. Proceedings of the Royal Irish Academy, $114 C, 1-34$.

Dumont, J. (1985). A microwear analysis of flints from the Mesolithic sites of Star Carr, Yorkshire, and Mount Sandel, Northern Ireland. Unpublished PhD Thesis, University of Oxford, Oxford.

Dumont, J. V. (1988). A microwear analysis of selected artefact types from the Mesolithic sites of Star Carr and Mount Sandel (Vol. 187). Oxford: British Archaeological Reports.

Elliot, T. (2018). The Mesolithic in the Marches: Lithic sourcing in the Wye Valley, UK. PhD Thesis. Worcester: University of Worcester.

Evans, A. A. (2009). Use wear studies on Mesolithic material. PhD Thesis, University of Bradford, Bradford.

Evans, A. A., Langer, J. L., Donahue, R. E., Wolframm, Y. B., \& Lovis, W. A. (2010). Lithic raw material sourcing and the assessment of Mesolithic landscape organisation and mobility strategies in Northern England. The Holocene, 20(7), 1157-1163.

Evans, A. A., Wolframm, Y. B., Donahue, R. E., \& Lovis, W. A. (2007). A pilot study of 'black chert' sourcing and implications for assessing hunter-gatherer mobility strategies in northern England. Journal of Archaeological Science, 34(12), 2161-2169.

Finlay, N. (2000). Microliths in the making. In R. Young (Ed.), Mesolithic lifeways: Current research from Britain and Ireland (Vol. 7, pp. 23-31). University of Leicester.

Finlay, N. (2003). Microliths and multiple authorship. In L. Larsson, H. Kindgren, K. Knutsson, D. Loeffler, \& A. Akerlund (Eds.), Mesolithic on the move: Papers presented at the sixth international conference on the Mesolithic in Europe, Stockholm 2000 (pp. 169-176). Oxford: Oxbow.

Fitch, S., \& Gaffney, V. (2011). West coast palaeo-landscapes survey. Birmingham: Institute of Archaeology and Antiquity, University of Birmingham.

Fraser, F. C., \& King, J. E. (1954). Faunal remains. In J. G. D. Clark (Ed.), Excavations at Star Carr: An Early Mesolithic site at Seamer near Scarborough, Yorkshire (pp. 70-95). Cambridge: Cambridge University Press.

Gaffney, V. L., Fitch, S., \& Smith, D. N. (2009). Europe's lost world: The rediscovery of Doggerland. York: Council for British Archeology.

Gaffney, V. L., Thomson, K., \& Fitch, S. (2007). Mapping Doggerland: The Mesolithic landscapes of the southern North Sea. Oxford: Archaeopress.

Gooder, J. (2007). Excavation of a Mesolithic house at East Barns, East Lothian Scotland: An interim report. In C. Waddington \& K. Pedersen (Eds.), Mesolithic studies in the North Sea Basin and beyond: Proceedings of a conference held at Newcastle in 2003 (pp. 49-59). Oxford: Oxbow.

Gusinde, M. (1982a). Los Indios de Tierra del Fuego: Los Selk'nam (Vol. I). Buenos Aires: Centro Argentino de Etnología Americana/Consejo Nacional de Investigaciones Científicas y Técnicas.

Gusinde, M. (1982b). Los Indios de Tierra del Fuego: El mundo espiritual de los Selk'nam (Vol. I, 2). Buenos Aires: Centro Argentino de Etnología Americana/Consejo Nacional de Investigaciones Científicas y Técnicas.

Hardy, K. (2009). Hunters and gatherers on the edge: Foraging for the past at continental limits. Antiquity, 83(320). http://www.antiquity.ac.uk/projGall/hardy/.

Hind, D. (2004) Picking up the trail: People, landscapes and technology in the Peak District of Derbyshire during the fifth and fourth millennia BC. In A. M. Chadwick (Ed.), Stories from the landscape: Archaeologies of inhabitation. BAR International Series 1238 (pp. 130-176). Oxford: Archaeopress.

Inizan, M. L., Renduron-Ballinger, M., Roche, H., \& Tixier, J. (1999). Technology and terminology of knapped stone (Vol. 5). Nanterre: Cercle de Recherches et d'Études Préhistoriques, avec le concours du Centre National de la Recherche Scientifique, France.

Jacobi, R. M. (1978). Northern England in the eighth millennium BC: An essay. In P. Mellars (Ed.), The early postglacial settlement of northern Europe: An ecological perspective (pp. 295-332). London: Duckworth.

Jochim, M. A. (1991). Archaeology as long-term ethnography. American Anthropologist, 93, 308-321.

Jordan, P. D. (2003). Investigating post-glacial hunter-gather landscape enculturation: Ethnographic analogy and interpretive methodologies. In L. Larsson, H. Kindgren, K. Knutsson, D. Loeffler, \& A. Akerlund (Eds.), Mesolithic on the move: Papers presented at the sixth international conference on the Mesolithic in Europe, Stockholm 2000 (pp. 128-138). Oxford: Oxbow.

Kador, T. (2007). Stone Age motion pictures: An object's perspective from early prehistoric Ireland. In R. Johnston \& V. Cummings (Eds.), Prehistoric journeys (pp. 33-44). Oxford: Oxbow. 
Kador, T. (2009a). Moving perceptions: Movement, mobility and the material dimension. In S. McCarton, R. Schulting, G. M. Warren, \& P. C. Woodman (Eds.), Mesolithic horizons: Papers presented at the seventh international conference on the Mesolithic in Europe, Belfast 2005 (pp. 73-79). Oxford: Oxbow.

Kador, T. (2009b). Prehistoric chain reactions: Stories that help us understand the distant past (pp. 31-41). Oxford: Prehistoric Society Research.

Kador, T. (2010). The last of the old: A homogeneous Later Mesolithic Ireland? In B. Finlayson \& G. Warren (Eds.), Landscapes in transition (pp. 147-160). Oxford: Oxbow.

Kador, T. (2013). Taking on the final frontier: Movement, mobility and social change in early prehistoric Ireland. In P. R. Preston \& K. Schörle (Eds.), Mobility, transition, and change in prehistory and antiquity. Proceedings of the graduate archaeology organisation conference on the 4th and 5th of April 2008 at Hertford College, Oxford, UK. Vol. 2534 (pp. 17-28). Oxford: Archaeopress.

Kador, T., Fibiger, L., Cooney, G., \& Fullagar, P. (2015). Movement and diet in early Irish prehistory: First evidence from multi-isotope analysis. Journal of Irish Archaeology, 23, 83-96.

Kelly, R. L. (1983). Hunter-gatherer mobility strategies. Journal of Anthropological Research, 39, 277-306.

Kelly, R. L. (1992). Mobility/Sedentism: Concepts, archaeological measures, and effects. Annual Review of Anthropology, 21, 23.

Kelly, R. L. (1995). The foraging spectrum: Diversity in hunter-gatherer lifeways. Washington/London: Smithsonian Institution Press.

Lazaridis, I., Patterson, N., Mittnik, A., Renaud, G., Mallick, S., Kirsanow, K., et al. (2014). Ancient human genomes suggest three ancestral populations for present-day Europeans. Nature, 513, 409-413.

Leary, J., \& Kador, T. (Eds.). (2016). Moving on in Neolithic studies: Understanding mobile lives. Neolithic Studies Group Seminar Papers 14. Oxford: Oxbow.

Legge, A. J., \& Rowley-Conwy, P. (1988). Star Carr revisited: A re-analysis of the large mammals. London: University of London.

Little, A. P. (2009a) The island and the hill: Extracting scales of sociability from a Mesolithic chert quarry. In N. Finlay, S. McCartan, N. Milner \& C. Wickham-Jones (Eds.), From bann flakes to bushmills: Papers in honour of Professor Peter Woodman. Prehistoric Society Research Papers 1 (pp. 133-142). Oxford: Oxbow.

Little, A. P. (2009b). Fishy settlement patterns and their social significance: A case study from the north Midlands of Ireland. In S. McCarton, R. Schulting, G. M. Warren, \& P. C. Woodman (Eds.), Mesolithic horizons: papers presented at the seventh international conference on the Mesolithic in Europe, Belfast 2005 (pp. 698-705). Oxford: Oxbow.

Lovis, W. A., \& Donahue, R. E. (2011). Space, information, and knowledge: Ethnocartography and North American Boreal forest hunter-gatherers. In R. Whallon, W. A. Lovis, \& R. K. Hitchcock (Eds.), Information and its role in hunter-gather band level socities (pp. 59-84). Los Angeles: Cotsen Institute of Archaeology, University of California.

Lovis, W. A., \& Donahue, R. E. (2015). Transient campsites, logistic campsites, and the cumulative taphonomy of Malham Tarn Site A: A persistent place in the Northern Pennines. Paper presented at the 9th international conference on Mesolithic Europe Belgrade, Serbia, 14th-18th September 2015.

Lovis, W. A., Donahue, R. E., Evans, A. A., Pedersen, K. L. R., \& Russ, H., (2008). Reassessing current models of hunter-gatherer mobility in Northern England and Southern Scotland. Unpublished conference paper. Presented at the challenging frontiers: Mobility, transition, and change conference, 4th-5th April 2008, Hertford College, Oxford.

Lovis, W. A., Donahue, R. E., \& Holman, M. B. (2005). Long-distance logistic mobility as an organizing principle among northern hunter-gatherers: A Great Lakes Middle Holocene settlement system. American Antiquity, 70(4), 669-693. https://doi.org/10.2307/40035869.

McCartan, S. (2003). Mesolithic hunter-gatherers in the Isle of man: Adaptations to an island environment? In L. K. Larsson, H. Kindgren, K. Knutsson, D. Loeffler, \& A. Akerlund (Eds.), Mesolithic on the move: Papers presented at the sixth international conference on the Mesolithic in Europe, Stockholm 2000 (pp. 331-339). Oxford: Oxbow Books.

McFadyen, L. (2006). Landscape. In C. Conneller \& G. Warren (Eds.), Mesolithic Britain and Ireland: New approaches (pp. 121-138). Stroud: Tempus.

McQuade, M., \& O’Donnell, L. (2007). Late Mesolithic fish traps from the Liffey estuary, Dublin. Ireland. Antiquity, 81(313), 569-584. 
Mellars, P. (1976). Settlement patterns and industrial variability in the British Mesolithic. In G. de Sieveking, I. H. Longworth, K. E. Wilson, \& G. Clark (Eds.), Problems in economic and social archaeology (pp. 375-399). London: Duckworth.

Mellars, P., \& Dark, P. (1998). Star Carr in context: New archaeological and palaeoecological investigations at the Early Mesolithic site of Star Carr, North Yorkshire. Cambridge: McDonald.

Mellars, P., \& Payne, S. (1971). Excavation of two Mesolithic shell middens on the island of Oronsay (Inner Hebrides). Nature, 231, 397-398.

Milner, N., \& Woodman, P. C. (2005). Looking into the canon's mouth: Mesolithic studies in the 21st Century. In N. Milner \& P. C. Woodman (Eds.), Mesolithic studies at the beginning of the 21st century (pp. 1-13). Oxford: Oxbow.

Myers, A. M. (1986). The organisational and structural dimensions of hunter-gatherer lithic technology: Theoretical perspectives from ethnography and ethnoarchaeology applied to the Mesolithic of mainland Britain with a case study from northern England. PhD thesis. University of Sheffield.

Myers, A. (1987). All shot to pieces? Inter-assemblage variability, lithic analysis and Mesolithic assemblage types: Some preliminary observations. In A. G. Brown \& M. R. Edmonds (Eds.), Lithic analysis and later British prehistory: Some problems and approaches (Vol. 162, pp. 137-153). Oxford: British Archaeological Reports.

Myers, A. M. (1989a). Reliable and maintainable technological strategies in the Mesolithic of mainland Britain. In R. Torrence (Ed.), Time, energy and stone tools (pp. 78-91). Cambridge: Cambridge University Press.

Myers, A. M. (1989b). Lithics, risk and change in the Mesolithic. In I. Brooks \& P. Phillips (Eds.), Breaking the stony silence: Papers from the Sheffield lithics conference 1988 (pp. 131-160). Oxford: British Archaeological Reports.

Myers, A. M. (2015). A flint for all seasons. In N. Ashton \& C. Harris (Eds.), No stone unturned: Papers in honour of Roger Jacobi (pp. 167-190). London: Lithic Studies Society.

Pettitt, P. B., Rockman, M., \& Chenery, S. (2015). Lithic raw materials and final Magdalenian mobility strategies at Creswell Crags, UK: New LA-ICP-MS trace elemental analysis of lithic artefacts and their implications. In N. Ashton \& C. Harris (Eds.), No stone left unturned: Papers in honour of Roger Jacobi (pp. 101-112). London: Lithic Studies Society.

Pitts, M. W. (1979). Hides and antlers: A new look at the gatherer-hunter site at Star Carr, North Yorkshire, England. World Archaeology, 11, 32-42.

Preston, P. R. (2009). Cache and carry: Lithic technology and Mesolithic mobility. Internet Archaeology. https://doi.org/10.11141/ia.26.25.

Preston, P. R. (2011). Lithics to landscapes: Hunter-gatherer tool use, resource exploitation and mobility during the Mesolithic of the Central Pennines, England. D.Phil. Thesis, University of Oxford

Preston, P. R. (2013a). Bones, stones or ethnography? Challenging the Mesolithic mobility models for Northern England. In P. R. Preston \& K. Schörle (Eds.), Mobility, transition, and change in prehistory and antiquity: Proceedings of the graduate archaeology organisation conference on the 4th and 5th of April 2008 at Hertford College, Oxford, UK. Vol. 2534 (pp. 29-48). Oxford: Archaeopress.

Preston, P. R. (2013b). New perspectives on Central Pennine Mesolithic lithic scatters. The Archaeological Forum, New Series, 2, 7-26.

Preston, P. R. (2018). All 'roads' lead to stone: Towards a more nuanced perspective on landscape, mobility, and technology in the British Mesolithic. In A. Myers, \& P. R. Preston (Eds.), The Mesolithic of north-western England. Archaeology Northwest, New Series 4 (pp. 236-286). Salford: Council for British Archaeology Northwest/Lithoscapes Archaeological Research Foundation/ Department of Applied Archaeology, University of Salford.

Richards, M. P., Schulting, R. J., \& Hedges, R. E. M. (2003). Archaeology. Sharp shift in diet at onset of Neolithic. Nature, 425, 366-366.

Robertson, A., Lochrie, J., \& Timpany, S. (2013). Built to last: Mesolithic and Neolithic settlement at two sites beside the Forth estuary, Scotland. Proceedings of the Society of Antiquaries of Scotland, 143, $1-64$.

Robson, H. K., Little, A., Jones, A. K. G., Blockley, S., Candy, I., Matthews, I., et al. (2018). Scales of analysis: Evidence of fish and fish processing at Star Carr. Journal of Archaeological Science: Reports, 17, 895-903. https://doi.org/10.1016/j.jasrep.2016.02.009.

Rockman, M. (2003). Landscape learning in the Late Glacial recolonization of Britain. PhD Thesis, University of Arizona. 
Saville, A. (1994). Exploitation of lithic resources for stone tools in earlier prehistoric Scotland. In N. Ashton \& A. David (Eds.), Stories in stone. Occasional Paper No. 4 (pp. 57-70). Oxford: Lithic Studies Society.

Saville, A. (1999). A cache of flint axeheads, and other flint artefacts from Auchenhoan, near Campbelltown, Kintyre, Scotland. Proceedings of the Prehistoric Society, 65, 83-123.

Saville, A. (2003). Indications of regionalisation in Mesolithic Scotland. In L. K. Larsson, H. Kindgren, K. Knutsson, D. Loeffler, \& A. Akerlund (Eds.), Mesolithic on the move: Papers presented at the sixth international conference on the Mesolithic in Europe, Stockholm 2000 (pp. 340-350). Oxford: Oxbow Books.

Schulting, R. J. (2005). '... Pursuing a rabbit in Burrington Combe': New research on the Early Mesolithic burial cave of Aveline's Hole. Proceedings of the University of Bristol Spelaeological Society, 23(3), 171-265.

Schulting, R. J., \& Richards, M. P. (2000). Mesolithic subsistence and seasonality: The use of stable isotopes in studies of subsistence and seasonality in the British Mesolithic. In R. Young (Ed.), Mesolithic lifeways: Current research from Britain and Ireland (pp. 55-65). Leicester: University of Leicester.

Schulting, R. J., \& Richards, M. P. (2002a). Dogs, ducks, deer and diet: New stable isotope evidence on Early Mesolithic dogs from the Vale of Pickering, northeast England. Journal of Archaeological Science, 29, 327-333.

Schulting, R. J., \& Richards, M. P. (2002b). Finding the coastal Mesolithic in southwest Britain: AMS dates and stable isotope results on human remains from Caldey Island, South Wales. Antiquity, 76, 1011-1025.

Schulting, R. J., \& Richards, M. P. (2009). Dogs, divers, deer and diet: Stable isotope results from Star Carr and a response to Dark. Journal of Archaeological Science, 36, 498-503. https://doi.org/10. 1016/j.jas.2008.09.035.

Simmons, I. G. (1975). The ecological setting of Mesolithic Man in the highland zone. In J. G. Evans, H. Cleere, \& S. Limbrey (Eds.), The effect of Man on the landscape: The highland zone (pp. 63-69). London: Council for British Archaeology.

Skoglund, P., Malmström, H., Omrak, A., Raghavan, M., Valdiosera, C., Günther, T., et al. (2014). Genomic diversity and admixture differs for Stone-Age Scandinavian foragers and farmers. Science, 344(6185), 747-750.

Smith, C. (1992). Late Stone Age hunters of the British Isles. London: Routledge.

Spikins, P. A. (1996). Rivers, boundaries and change: A hypothesis of changing settlement patterns in the Mesolithic of Northern England. In A. J. Pollard \& A. Morrison (Eds.), The early prehistory of Scotland (pp. 87-107). Edinburgh: Edinburgh University Press for the University of Glasgow.

Spikins, P. A. (1999). Mesolithic northern England: Environment, population and settlement. Oxford: Archaeopress.

Spikins, P. A. (2000). Ethno-fact or ethno-fiction? Searching for the 'structure' of settlement patterns. In R. Young (Ed.), Mesolithic lifeways: Current research from Britain and Ireland (pp. 105-118). Leicester: University of Leicester.

Thomas, J. (1996). Time, culture and identity: An interpretive archaeology. London: Routledge.

Thomas, J. (2004). Current debates on the Mesolithic-Neolithic transition in Britain and Ireland. Documenta Praehistorica, 31, 113-130.

Thomson, D. (1949). Economic structure and ceremonial exchange in Arnhem Land. Melbourne: Macmillan.

Tilley, C. (1993). Art, architecture, landscape [Neolithic Sweden]. In B. Bender (Ed.), Landscape politics and perspectives (pp. 49-84). Oxford: Berg.

Tilley, C. (1994). A phenomenology of landscape: Places, paths and monuments. Oxford: Berg.

Tilley, C. (1995). Rocks as resources: Landscape and power. Cornish Archaeology, 34, 5-57.

Tilley, C. Y., \& Bennett, W. (2004). The materiality of stone (Vol. 1). Oxford: Berg.

Torrence, R. (1983). Time budgeting and hunter-gatherer technology. In G. N. Bailey (Ed.), Huntergatherer economy in prehistory: A European perspective (pp. 11-22). Cambridge: Cambridge University Press.

Torrence, R. (Ed.). (1989). Time, energy and stone tools. Cambridge: Cambridge University Press.

Waddington, C. (2007). Mesolithic settlement in the North Sea Basin: A case study from Howick, northeast England. Oxford: Oxbow. 
Waddington, C. (2015). Mesolithic recolonisation of Britain following the drowning of North Sea landscapes. In N. Ashton \& C. Harris (Eds.), No stone unturned: Papers in Honour of Roger Jacobi (pp. 221-232). London: Lithic Studies Society.

Warren, G. M. (2000). Seascapes: People, boats and inhabiting the later Mesolithic in western Scotland. In R. Young (Ed.) Mesolithic lifeways: Current research from Britain and Ireland (pp. 97-104). Leicester: Leicester Archaeology Monographs.

Warren, G. M. (2005). Mesolithic lives in Scotland. Stroud: Tempus.

Warren, G. M. (2006). Technology. In C. Conneller \& G. M. Warren (Eds.), Mesolithic Britain and Ireland: New approaches (pp. 13-34). Stroud: Tempus.

Warren, G., Little, A., \& Stanley, M. (2009). A Late Mesolithic lithic scatter from Corralanna, Co. Westmeath, and its place in the Mesolithic landscape of the Irish Midlands. Proceedings of the Royal Irish Academy, 109C, 1-35.

Wessex Archaeology. (2006). Engand's historic seascapes final report (Report reference No 58370.06). Salisbury: Wessex Archaeology. https://doi.org/10.5284/1007741.

Wickham-Jones, C. (2005). Summer walkers? Mobility and the Mesolithic. In N. Milner \& P. C. Woodman (Eds.), Mesolithic studies at the beginning of the 21st century (pp. 30-41). Oxford: Oxbow.

Wolframm, Y. B. (2006). Investigating Mesolithic hunter-gatherer mobility through chert exploitation in Northern England: An application for the non-destructive technique of LA-ICP-MS for sourcing Pennine chert to investigate mesolithic hunter-gatherer mobility strategies in northern England. $\mathrm{PhD}$ Thesis, University of Bradford.

Woodman, P. C. (1985). Excavations at Mount Sandel 1973-77: County Londonderry (Vol. 2). Belfast: H.M.S.O.

Woodman, P. C. (1987). Excavations of Cass ny Hawin, a Manx Mesolithic site, and the position of the Manx microlithic industries. Proceedings of the Prehistoric Society, 53, 1-22.

Woodman, P. (2000). Transitions to farming in Ireland and Britain. In Europe's first farmers (p. 395). Cambridge: Cambridge University Press.

Woodman, P. C. (2004). The exploitation of Ireland's coastal resources-marginal resources through time? In M. Gonzales-Morales \& G. A. Clark (Eds.), The Mesolithic of the Atlantic Façade: Proceedings of the Santander symposium (pp. 37-56).

Woodman, P. C., Anderson, E., \& Finlay, N. (1999). Excavations at Ferriter's Cove 1983-1995: Last foragers, first farmers in the Dingle Peninsula. Dublin: Wordwell.

Woodman, P. C., Finlay, N., \& Anderson, E. (2006). The archaeology of a collection: The KeillerKnowles collection of the National Museum of Ireland. National Museum of Ireland Monograph Series 2. Dublin: Wordwell.

Woodman, P. C., \& Johnston, I. (1991). A petrological examination of some Mesolithic stone artefacts. Ulster Journal of Archaeology, 54, 134-137.

Zvelebil, M. (1984). Archaeology: Clues to recent human evolution from specialised technologies? Nature, 307, 314-315. 